\title{
PERANCANGAN SISTEM INFORMASI PENJUALAN BERBASIS WEB PADA RAHAYU PHOTO COPY DENGAN METODE MySQL
}

\author{
Mohammad Ahmadar'), Perwito,S.E.,MM²) \\ ${ }^{1,2)}$ Program Studi Komputerisasi Akuntansi, Politeknik Piksi Ganesha Bandung \\ email: m.ahmadar@unpad.ac.id ${ }^{1)}$
}

\begin{abstract}
Abstrak: Penelitian ini bertujuan untuk membangun sebuah sistem informasi penjualan pada Rahayu Photo Copy berbasis web. Sistem ini dikembangkan menggunakan bahasa pemrograman PHP dengan menggunakan MySQL sebagai database. Metode pengumpulan data yang dilakukan yaitu dengan cara wawancara, observasi, dan ditambah dengan studi pustaka yang memiliki kaitan dengan masalah yang dihadapi. Sedangkan metode penelitian yang digunakan adalah penelitian kualitatif yang bersifat deskriptif dengan sitem pengembangan model Waterfall.

Dari penelitian yang dilakukan ditemukan masalah seperti : 1) Seringkali terjadi kehilangan nota transaksi, 2) tidak tersusun dengan teratur transaksi penjualan, dan 3) Pencatatan secara manual kurang rapih, sehingga mengakibatkan kesulitan dalam pencacatan transaksi dan juga kesalahan dalam pencacatan laporan akhir bulannya. Adapun upaya pemecahan masalah tersebut yaitu dengan membuat sistem informasi penjualan berbasis web menggunakan MySQL.
\end{abstract}

Kata kunci: Perancangan Sitem Informasi, Penjualan, Bahan Baku, MySQL.

Abstract: The research aims to build a sales information system on the Rahayu Photo Copy based on the web. The system was developed using the PHP programming language using MySQL as a database.

The method of data collection is done by way of interviews, observation, and coupled with a study of the library which has a connection with the problems faced. While the research method used is the descriptive qualitative research with the Waterfall model development system.

From research conducted, found problems such as; 1) Often lost transaction notes, 2) not regularly structured sales transactions, and 3) Manual recording is not neat, resulting in difficulties in recording transactions and also errors in recording the end of month reports. The effort to solve this problem is by creating a web-based sales information system using $M y S Q L$.

Keyword: Design of information system, Purchasing, Raw materials, MySQL.

\section{PENDAHULUAN}

Berkembangnya usaha - usaha perdagangan yang sangat pesat pada saat ini menjadikan informasi sebagai hal yang sangat penting peranannya dalam menunjang jalannya operasi - operasi sistem teknologi demi tercapainya tujuan yang diinginkan perusahaan. Teknologi internet sudah terbukti merupakan salah satu media informasi yang efektif dan efesien dalam penyebaran informasi yang dapat diakses oleh siapa saja, kapan saja dan dimana saja. Teknologi internet mempunyai efek yang sangat besar pada perdagangan atau bisnis. Hanya dari rumah atau ruang kantor, calon pembeli dapat melihat produk - produk pada layar komputer, mengakses informasinya, memesan dan membayar dengan pilihan yang tersedia. Calon pembeli dapat menghemat waktu dan biaya karena tidak perlu datang ke toko atau tempat transaksi.

Hal ini terbukti dengan digunakannya komputer dalam kehidupan sehari - hari dalam semua aspek kehidupan, seiring dengan perkembangan teknilogi semua hal atau informasi dapat ditemukan melalui website.

Dengan menggunakan website, semua informasi dan berita dapat diakses dimana dan kapan saja, website juga sebagai salah satu alternatif strategi untuk pemesanan dan penjualan, perusahaan membutuhkan website untuk membantu dalam hal pemesanan dan penjualan.

Perusahaan yang berada di level menengah ke bawah (kecil) yang menjual berbagai macam produk alat tulis kantor (ATK) yang masih menggunakan nota ataupun agenda yaitu dengan cara pencatatan nota penjualan, nota-nota ini dikumpulkan dan dicatat kembali ke dalam pembukuan sebagai pencatatan transaksi mingguan dan bulanan, sedangkan dalam hal pemesanan, pelanggan harus datang langsung ke tempat usaha ini untuk melakukan proses transaksi.

Perusahaan kecil juga memiliki beberapa kendala dalam penjualan, seperti saat pengelolaan data penjualan yang terkadang terjadi kesalahan dalam pencatatan ataupun terjadi kehilangan nota yang tercecer ataupun tidak rapi sehingga menimbulkan selisih dalam pencatatan penjualan serta akibat dari pandemi Covid 19. Akibatnya omset penjualan sulit meningkat dan jumlah konsumen cenderung sedikit, dari hasil wawancara penulis bahwa omset yang didapat menurun drastis sampai $80 \%$, dan konsumen yang datang hanya berasal dari sekitar saja.

Berbagai permasalahan di atas memberi suatu pemikiran bagi penulis untuk merancang suatu sistem informasi penjualan. Sistem yang dibuat 
memiliki fitur untuk pembuatan laporan penjualan, stok barang dan pelanggan yang menggunakan bahasa pemrograman PHP dan MySQL sebagai Database Management System (DBMS) untuk penyimpanan data-data kegiatan penjualan.

\section{LANDASAN TEORI}

\section{Sistem Informasi}

Peneliti melakukan studi literatur untuk mengumpulkan data-data atau sumber-sumber yang berhubungan dengan topik permasalahan yang dibahas dalam suatu penelitian. Studi literatur bisa didapat dari berbagai sumber, jurnal, buku dokumentasi, internet dan pustaka.

Menurut (R. Supriati, A. S. Saputra, dan S. S. Islamiah, 2018), Sistem dapat didefinisikan dengan mengumpulkan, memproses, menyimpan, menganalisis, menyebarkan informasi untuk tujuan tertentu. Seperti sebuah sistem informasi terdiri atas input (data, intruksi) dan output (laporan, kalkulasi).

Menurut (D. D. Saputra dan S. Sudarmaji, 2017), Sistem adalah suatu bentuk jaringan kerja yang saling berhubungan antara satu dengan yang lain untuk membentuk suatu kesatuan dalam mencapai suatu tujuan.

Menurut I Putu Agus Eka Pratama (2014: 10), Sistem Informasi merupakan gabungan dari empat bagian utama, keempat bagian utama tersebut mencakup perangkat lunak (software), perangkat keras (hardware), infrastruktur, dan sumber daya manusia yang terlatih.

Jadi dapat disimpulkan bahwa Sistem Informasi adalah kombinasi dari teknologi informasi dan aktivitas orang yang menggunakan teknologi itu untuk mendukung operasi dan manajemen.

Menurut Rangkuti (2009: 20) mendefinisikan bahwa penjualan adalah pemindahan hak milik atas barang atau pemberian jasa yang dilakukan penjualan kepada pembeli dengan harga disepakati bersama dengan jumlah yang dibebankan kepada pelanggan dalam penjualan barang dan jasa dalam suatu periode akuntansi.

Riandy (2011: 2) mengemukakan penjualan adalah suatu usaha yang terpadu yang bertujuan untuk mengembangkan rencana-rencana yang diarahkan untuk pemuasan dan kebutuhan serta keinginan pembeli yang menghasilkan laba penjualan.

\section{Perancangan Sistem}

Perancangan sistem merupakan penentuan proses dan data yang diperlukan oleh sistem baru, jika sistem itu berbasis komputer, perancangan dapat menyertakan spesifikasi peralatan yang akan digunakan. Untuk dapat mencapai yang dimaksud, perlu dilakukan suatu rancangan sistem.

\section{Penjualan}

Menurut Ikatan Akuntan Indonesia, penjualan adalah peningkatan jumlah aktiva atau penurunan jumlah kewajiban suatu badan usaha yang timbul dari penyerahan barang dagang/jasa atau aktivitas lainnya didalam suatu periode.

Menurut (Rogi Gusrizaldi dan Eka Komalasari, 2016), Penjualan merupakan syarat mutlak keberlangsungan suatu usaha, karena dengan penjualan maka akan didapatkan keuntungan.

\section{Pengenalan Web Dan Basis Data}

Website diartikan sebagai kumpulan halaman-halaman yang digunakan untuk menampilkan informasi teks, gambar diam atau gerak, animasi, suara dan atau gabungan dari semuanya, baik brsifat statis maupun dinamis yang membentuk suatu rangkaian bangunan yang saling terkait, yang masing-masing dihubungkan dengan jaring-jaringan halaman.

Basis data adalah kumpulan informasi yang disimpan didalam komputer secara sistematik sehingga dapat diperiksa menggunakan suatu program komputer untuk memperoleh informasi dari basis data tersebut. Perangkat lunak yang digunakan untuk mengelola dan memanggil kueri (query) basis data disebut sistem manajemen basis data (database management system, DBMS). Konsep dasar dari basis data adalah kumpulan dari catatan - catatan , atau potongan dari pengetahuan.

\section{Alat Bantu Pengembangan Sistem}

Dua hal yang harus ada pada use case menurut Rosa A.S dan M.Salahuddin adalah :

1. Aktor merupakan orang, proses, atau aplikasi lain berinteraksi dengan aplikasi yang akan dibuat diluar aplikasi yang akan dibuat itu sendiri, jadi walaupun symbol dari aktor adalah gambar orang, tapi aktor belum tentu meruapakan orang.

2. Use case merupakan fungsi - fungsi/proses - proses yang disediakan aplikasi sebagai unit - unit yang saling bertukar pesan/berinteraksi antar unit/proses atau aktor.

Contoh use case diagram dapat dilihat pada gambar 1 berikut:

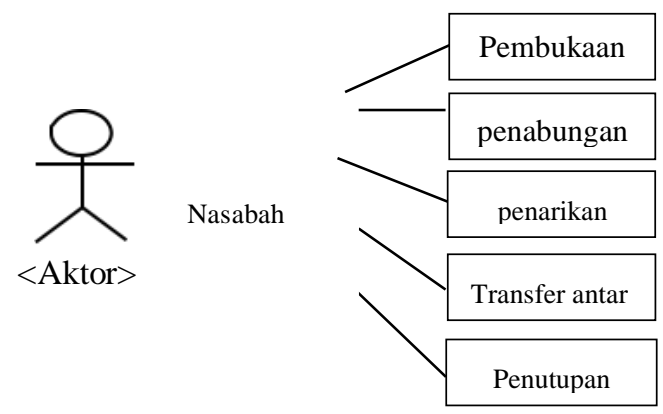




\section{Gambar 1. Use case Diagram}

\section{PHP}

PHP (dahulu dikenal sebagai Personal Home Page, sekarang PHP: Hypertext Preprocessor) yang merupakan program yang dikembangkan secara bersama oleh para programmer dari seluruh dunia yang menekuni dunia opensource. PHP dikembangkan khusunya untuk mengakses dan memanipulasi data yang ada di database server open source seperti MySQL (Teguh Wahyono, 2005, h.5).

\section{MySQL}

MySQL adalah sebuah program database server yang mampu menerima dan mengirimkan datanya dengan sangat cepat, multi user, serta menggunakan perintah standar SQL (Structured Query Language) (Bunafit Nugroho, 2005, h.1).

\section{Xampp}

Untuk membuat aplikasi berbasis web dengan menggunakan bahasa PHP, diperlukan sebuah server web dan interprenter PHP. XAMPP mengkombinasikan beberapa paket perangkat lunak berbeda kedalam satu paket.

Menurut Betha Sidik (2012: 72): "XAMPP merupakan paket server web PHP dan data base MYSQL yang paling populer di kalangan pengembang web dengan menggunakan PHP dan MYSQL sebagai data basenya".

\section{METODOLOGI PENELITIAN}

Penelitian ini termasuk penelitian kualitatif yang bersifat deskriptif. Menurut Moleong dalam Arikunto (2016) penelitian kualitatif yaitu tampilan yang berupa kata-kata lisan yang kemudian dicermati oleh peneliti, serta benda- benda yang diamati sampai dengan selesai agar dapat ditarik makna yang tersirat dalam dokumen atau berkas.

Selanjutnya bersifat deskriptif karena dalam pemecahan masalah yang di selidiki yaitu dengan menggambarkan keadaan subjek maupun objek yang diteliti pada saat sekarang berdasarkan fakta- fakta yang tampak sebagaimana adanya. Adapun metode pengumpulan data yang digunakan yaitu observasi, wawancara, dokumentasi, dan studi pustaka.

Untuk membantu dan mempermudah penelitian ini penulis melakukan penyusunan kerangka kerja (Framework) yang merupakan langkah - langkah, gambaran tahapan - tahapan kegiatan yang akan dilakukan selama penelitian. Adapun tahapan tahapan tersebut terlihat pada gambar:

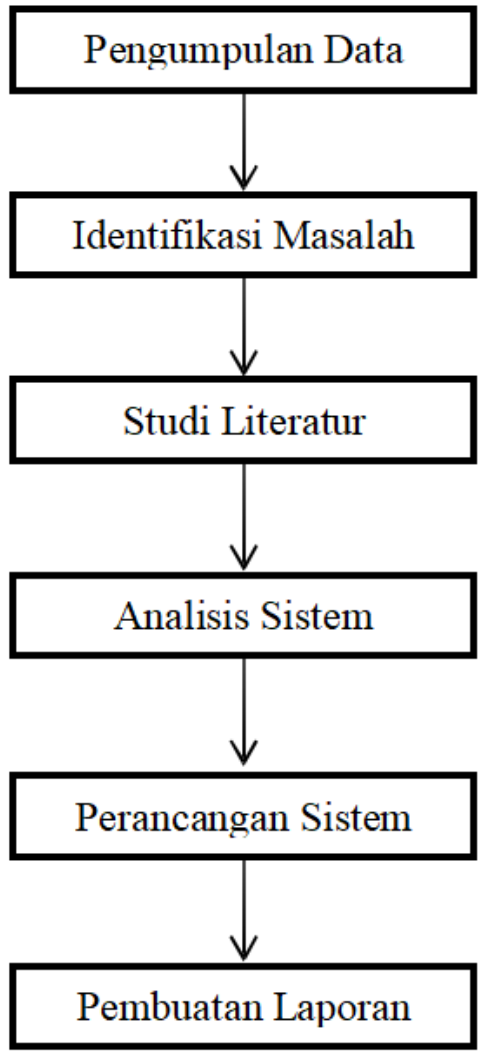

Gambar 2 Kerangka Kerja Penelitian

Metode yang digunakan dalam perancangan sistem ini adalah model waterfall (air terjun). Penulis menggunakan model waterfall dikarenakan langkah tersebut mudah dipahami dalam pengerjaan serta model waterfall memiliki kelebihan dapat kembali ketahap sebelumnya jika ada kesalahan dalam tahapan pengerjaannya. Adapun model waterfall yang digunakan dapat dilihat pada gambar 3.2 berikut:

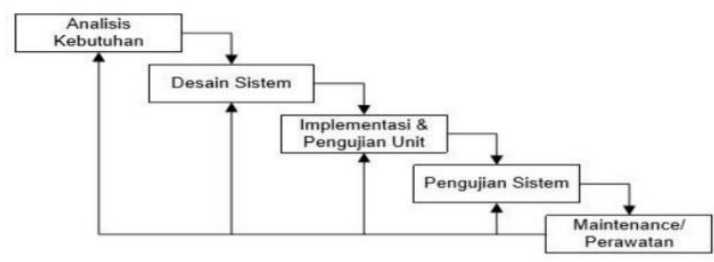

Gambar 3 Model Waterfall 


\section{ANALISIS DAN PERANCANGAN SISTEM}

\section{Analisis Permasalahan}

Berdasarkan hasil penelitian yang penulis lakukan terhadap sistem yang berjalan, maka terdapat beberapa kekurangan sistem yang sedang berjalan, antara lain:

1. Data mudah hilang dan lamban dalam melakukan pencarian karena belum terkomputerisasi.

2. Sulitnya dalam mendapatkan informasi fotokopi untuk pengambilan dokumen jika sudah diselesaikan pengerjaannya.

3. Proses pembuatan laporan yang relatif lama sehingga pemilik harus ekstra dalam membuat laporan.

Sistem yang sedang berjalan pada Rahayu Photo Copy dapat di gambarkan dengan Flowchart Dokumen sebagai berikut:

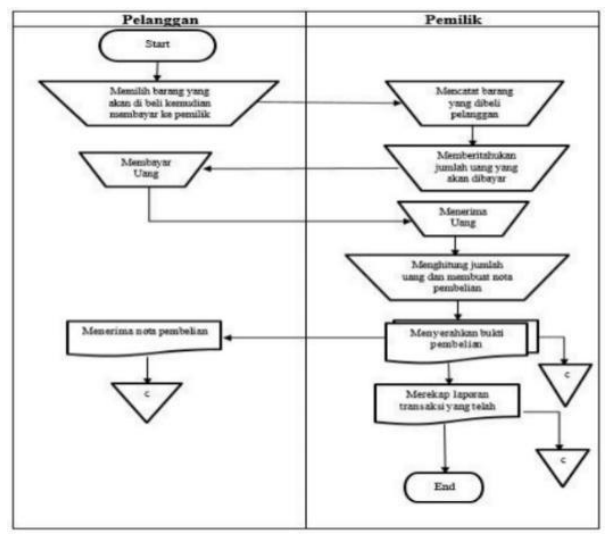

\section{Gambar 4 Flowchart Sistem Yang Berjalan pada Rahayu Photo Copy}

\section{Analisis Kebutuhan Sistem}

Dalam menganalisis suatu kebutuhan untuk mengembangkan suatu sistem informasi, penulis menggunakan pemodelan use case. Berikut ini merupakan gambar diagram use case sistem yang diusulkan pada Rahayu Photo Copy:

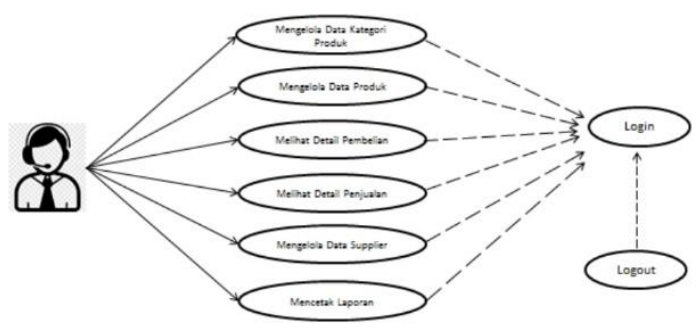

Gambar 5 Use Case Diagram

\section{Activity Diagram}

Pada dasarnya, diagram aktivitas adalah diagram flowchart yang diperluas yang menunjukan aliran kendali satu aktivitas ke aktivitas lain.

Diagram ini digunakan untuk memodelkan aspek dinamis sistem. Diagram aktivitas menggambarkan aliran fungsional sistem. Berikut ini adalah activity diagram perancangan aplikasi pada Rahayu Photo Copy.

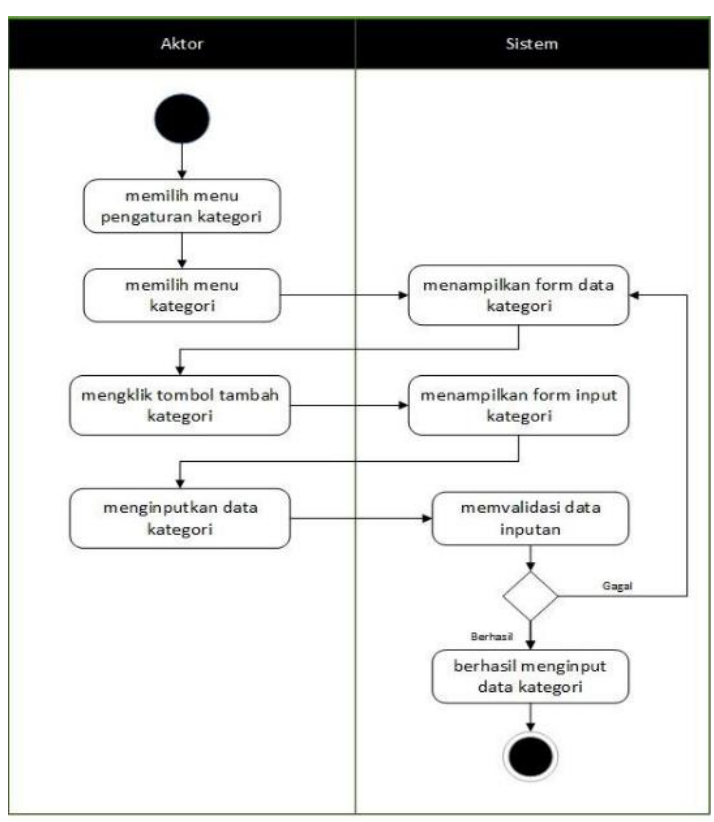

Gambar 6 Activity Diagram Input Data
Kategori

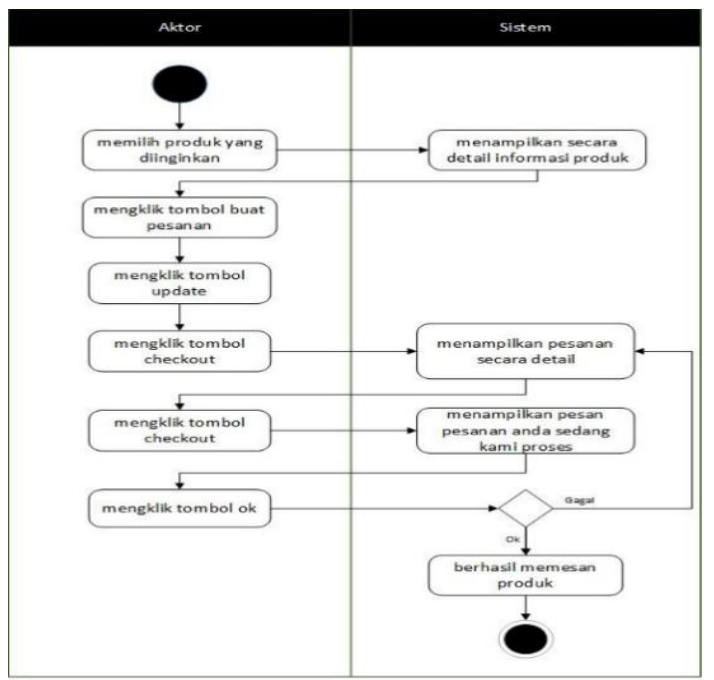

Gambar 7 Activity Diagram Pembelian Produk 


\section{Class Diagram}

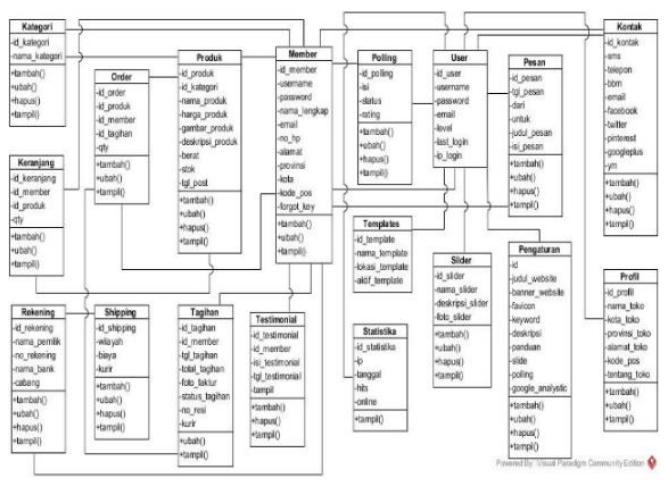

\section{Gambar 8 Class Diagram}

\section{Rancangan Perangkat Lunak}

Rancangan halaman utama admin adalah halaman yang pertama kali tampil ketika mengakses menu admin pada web Rahayu Photo Copy dimana disini admin mengelola segala hal tentang website yang di jalankan.

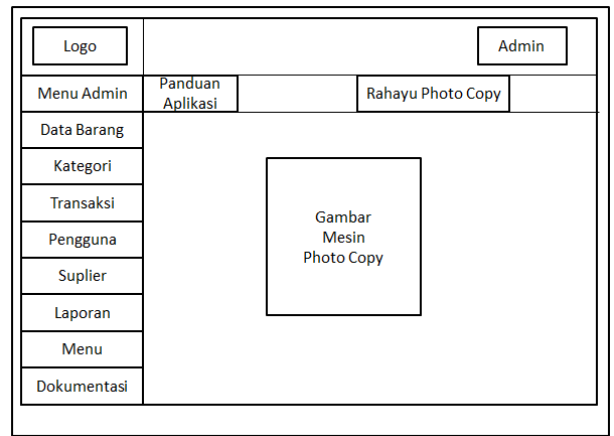

Gambar 9 Rancangan Halaman Utama Admin

\begin{tabular}{|c|c|c|c|c|c|c|c|}
\hline \multirow{2}{*}{ 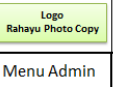 } & & & & & & \multicolumn{2}{|c|}{ Admin } \\
\hline & Tambah Barang & & & & File Exce & & \\
\hline Data Barang & \multicolumn{7}{|c|}{ 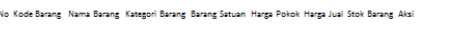 } \\
\hline Kategori & Broos Bapoint & ATix & $\operatorname{siah}$ & 2000 & 2500 & 10 & Eod Hapus \\
\hline Transaksi & BRos! Map Biole & ATix & Buan & 1700 & 2000 & 10 & Ese. Hapus \\
\hline Pengguna & $-\ldots$ & - & - & - & - & - & sea hapes \\
\hline Suplier & $-\ldots$ & - & - & - & - & - & Eset hasus \\
\hline Laporan & $-\ldots$ & - & - & - & - &.- & Eot hases \\
\hline Menu & $6 \quad-\ldots$ & - & - & - & - & $\ldots$ & sos hoous \\
\hline Dokumentasi & $-\ldots$ & - & - & - & - & - & Ese hapus \\
\hline
\end{tabular}

Gambar 10 Rancangan Tampil Data Produk

\section{Rancangan Struktur Data}

Pada desain file terbagi ke dalam beberapa tabel yang menampung record -record yang akan diinputkan. Adapun tabel tersebut adalah sebagai berikut :

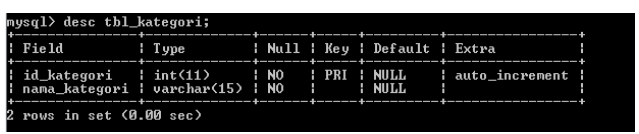

Tabel 1 Kategori

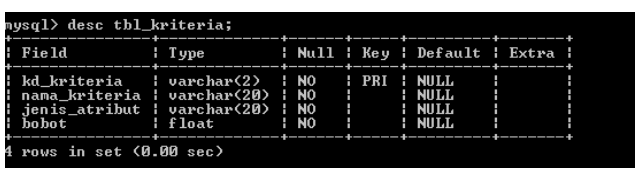

Tabel 2 Tabel Kriteria

\section{IMPLEMENTASI DAN PENGUJIAN SISTEM}

\section{Implementasi Program}

Implementasi pada bab ini merupakan hasil dari tampilan rancangan program yang telah dirancang berdasarkan rancangan output dan rancangan input, yang telah dirancang pada pembahasan di bab 4 . Adapun implementasi rancangan program input dan outputserta struktur dataantara lain adalah sebagai berikut :

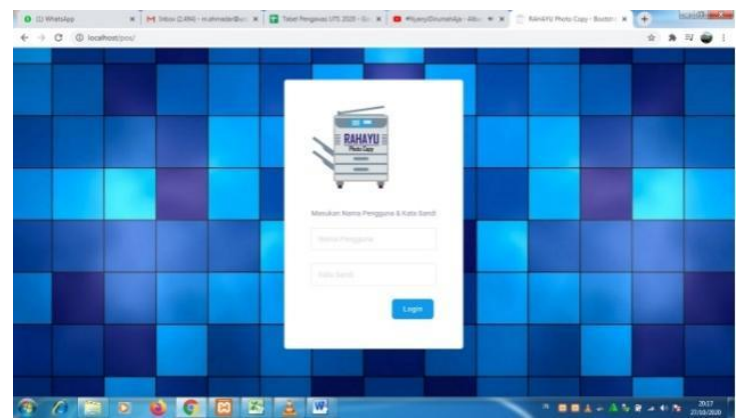

Gambar 11 Halaman Login

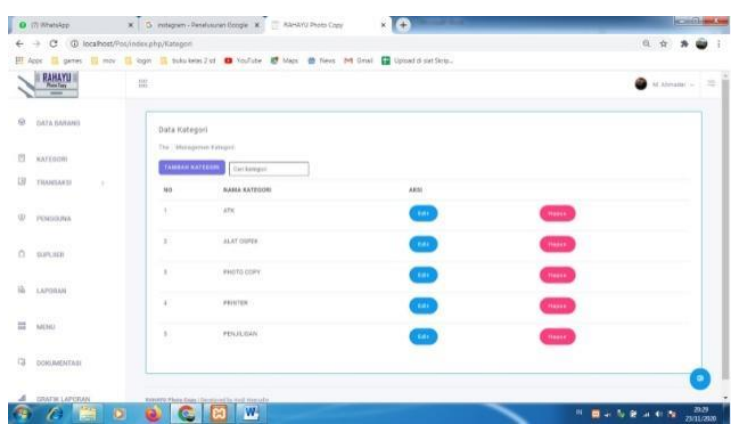

Gambar 12 Halaman Input Data Kategori 


\section{PENUTUP}

\section{Kesimpulan}

Setelah melakukan penelitian dan analisis untuk sistem penjualan pada Rahayu Photo Copy, maka penulis mengambil beberapa kesimpulan sebagai berikut:

1. Sistem Informasi Rahayu Photo Copy masih menggunakan buku agenda ataupun buku tulis sehingga ditemukan permasalahan, terjadi kesalahan dalam pencatatan, pencarian dan pembuatan laporan yang diperlukan, adanya pandemi, lalu omzet/penghasilan perbulan menggunakan sistem manual atau konvensional masih tergolong sedikit dari yang diharapkan.

2. Hasil dari Sistem Informasi Penjualan Berbasis Web Pada Rahayu Photo Copy yang menggunakan bahasa pemograman PHP dan MySQL sebagai database mampu memberikan kemudahan dalam melakukan pengolahan data secara terkomputerisasi dimana sistem dapat melakukan pengolahan data dan dapat meningkatkan omzet/penghasilan perbulan yang tidak terlalu signifikan dengan sistem manual atau konvensional.

\section{Saran}

Setelah melakukan penelitian untuk perancangan sistem penjualan pada Rahayu Photo Copy, maka penulis mencoba memberikan saran-saran diantaranya:

1. Perlunya untuk membuat laporan yang lebih baik lagi terhadap sistem yang telah dibuat terutama untuk pembuatan laporan keuangan seperti laporan laba rugi dan laporan biaya yang dikeluarkan serta tampilan yang rapi dan mudah dimengerti atau digunakan oleh user.

2. Perlu adanya pelatihan kepada sumber daya manusia (admin) dalam mengelola program yang akan digunakan.

3. Penelitian yang penulis lakukan ini diharapkan bisa menjadi referensi bagi penelitian yang lain dalam penulisan karya ilmiah ini.

\section{Daftar Pustaka}

[1] T. Sutabri, "Sistem Informasi Manajemen Edisi Revisi," 2017.

[2] Buana Alfa, Puspa. 2018. Sistem Informasi ECommerce Pada Toko Fotocopy Nicky Jakarta.

[3] Joseph, Rhio. 2018. Perancangan Sistem Informasi Penjualan Berbasis Web Pada CV. Cahaya Abadi Jambi.

[4] Farhan Ramadhan1), Nuraini Purwandari2) "Sistem Informasi Penjualan Berbasis Web Pada PT. Mustika Jati”, Available: http://research.kalbis.ac.id

[5] Sudaryono1 \& Efana Rahwanto2,
"Perancangan Sistem Informasi Penjualan Berbasis Web Pada PT. Inter Aneka Plasindo", Available: https://ejournal.stitpn.ac.id

[6] Arikunto, Suharsimi. 2016. Prosedur Penelitian. Penerbit: Rineka Cipta.

[7] Mulyani, Sri. 2016 Metode Analisis dan Perancangan Sistem.Bandung: Abdi Sistematika.

[8] Eri Sasmita Susanto1), Yana Karisma2),Susi Isnaeni 3), "Sistem Informasi Penjualan Pada Toko Jilbab Rjs Kabupaten Sumbawa Berbasis Web", Jurnal JINTEKS Vol.1 No.2 Available: https://jurnal.uts.ac.id

[9] Nandang Iriadi[1], Nia Rosdiana[2], "Perancangan Sistem Informasi Penjualan Minuman Kemasan Berbasis Web Pada Toko Bambu Sejahtera Bekasi”, Available: https://ejournal.bsi.ac.id

[10] Viviliana Siang, Margareta Susanto, Desy Iba Ricoida, "Perancangan Sistem Informasi Penjualan Berbasis Web pada Pempek Nony 168 Palembang”, Available: https://core.ac.uk

[11] Andi. 2016. Perancangan Sistem Informasi dan Aplikasinya. Yogyakarta: Gava Media.

[12] Basu Swastha. 2011. Manajemen Penjualan.

[13] Buana Alfa, Puspa. 2018. Sistem Informasi ECommerce Pada Toko Fotocopy Nicky Jakarta.

[14] Budi Raharjo. 2011. Panduan PHP. Bandung: Informatika Bandung.

[15] I Putu Agus Eka Pratama., 2014, Sistem Informasi dan Implementasinya. Bandung: Informatika Bandung. 